\title{
KAJIAN TEKS KENDALA PENGGUNAAN ISTILAH TEKNOLOGI INFORMASI BERBAHASA INDONESIA
}

\author{
Itsna Hadi Saptiawan \\ Universitas Mataram \\ itsnahs@gmail.com
}

\begin{abstract}
Abstrak
Istilah diciptakan sebagai intisari (rangkuman) suatu konsep agar dalam penyampaiannya dapat menjadi representasi pengalaman pengguna bahasa ketika berinteraksi dengan bidang yang berhubungan dengan penggunaan istilah tersebut. Fungsi komunikatif suatu istilah, dalam hal ini, dengan demikian berkaitan dengan fungsi praktisnya bagi para penggunanya. Jika suatu istilah hanya mengedepankan esensi konseptual tanpa mengindahkan pemahaman pengguna terhadap fungsi istilah tersebut, dimungkinkan penerapan istilah tersebut terbatas pada kalangan tertentu saja. Terkait dengan hal tersebut, penelitian ini berusaha mengungkap kendala yang dihadapi oleh istilah teknologi informasi berbahasa Indonesia yang kosakatanya diserap atau diterjemahkan dari bahasa asing. Fokus penelitian terletak pada asumsi akan digunakannya istilah tersebut oleh para pengguna. Sejalan dengan ini, uraian tentang peluang serta tantangan penerapan kosakata sejenis menjadi hal yang penting. Analisis dalam penelitian ini mengacu pada pendekatan komunikatif yang dikemukakan oleh Agnes Kukulska-Hulme. Hasilnya, ditemukan kendala konteks verbal baik itu konteks gramatikal maupun semantik dalam banyak padanan yang dihasilkan. Ambiguitas, termasuk ekspresi idiomatik menjadi dua contoh yang mengemuka. Ini belum termasuk penggunaan singkatan, istilah semi teknis, serta makna budaya tertentu yang memiliki asosiasi berbeda kepada para pengguna padanan istilah teknologi informasi tersebut.
\end{abstract}

Kata kunci: istilah TI, pendekatan komunikatif

\begin{abstract}
The term was created as an essence (summary) of a concept so that the delivery could be a representation of the language user's experience when interacting with a field related to the use of the term. Communicative function of a term, in this case, thus related to its practical functionality for its users. If a term is only put forward the conceptual essence regardless of the user's understanding of the function of the term, the application of the term could be limited to certain circles. Related to the fact above, this study seeks to uncover the obstacles faced by the term information technology in Indonesian language vocabulary absorbed or translated from foreign languages. The focus of research lies in the assumption in which the term will be used by users of information technology. In line with this, the description of the opportunities and challenges of the implementation of similar vocabulary becomes important. The analysis in this study refers to the communicative approach proposed by Agnes Kukulska-Hulme. As a result, verbal context both grammatical and semantic context appear as constraints in many equivalent produced. Ambiguity, including idiomatic expressions becomes the two prominent examples. This does not include the use of abbreviations, semi-technical terms, as well as specific cultural meanings that have different associations to the users of the information technology equivalent terms.
\end{abstract}

Keywords: information and technology terms, communicative approach

\section{PENDAHULUAN}

Sebagai wadah perkembangan bahasa, media memiliki peran vital dalam menjaga dan memelihara keberadaan suatu bahasa. Media cetak seperti koran, majalah, tabloid, dan jurnal memiliki tanggung ja- wab yang sama dengan media elektronik seperti televisi, radio, maupun internet dalam mempertahankan keberlangsungan suatu bahasa. Di Indonesia, peran ini telah diinisiasi oleh pemerintah melalui beberapa peraturan seperti Inpres Nomor 2 Tahun 
2001, Undang-Undang Nomor 11 Tahun 2008, dan Undang-Undang Nomor 24 Tahun 2009.

Pasal 25 sampai dengan pasal 45 Undang-Undang Nomor 24 Tahun 2009 menegaskan secara yuridis status, fungsi, penggunaan, pengembangan, pembinaan, serta pelindungan terhadap bahasa Indonesia. Pasal 39 ayat 1 secara spesifik menjelaskan kedudukan bahasa Indonesia dalam media massa:

\section{Pasal 39}

1) Bahasa Indonesia wajib digunakan dalam informasi melalui media massa

2) Media massa sebagaimana dimaksud pada ayat (1) dapat menggunakan bahasa daerah atau bahasa asing yang mempunyai tujuan khusus atau sasaran khusus.

Setahun sebelumnya, pemerintah mengeluarkan UU Nomor 11 Tahun 2008 Tentang Informasi dan Transaksi Elektronik. Meskipun tidak secara eksplisit menyatakan tugas pengembangan bahasa, perangkat hukum ini menyerukan perlunya batasan tentang norma bahasa ketika berbagi informasi atau saat bertransaksi secara elektronik. Gambaran umum tersebut diperoleh dari Bab VI sampai dengan Bab XI yang mengatur domain, HKI, perlindungan hak pribadi, perbuatan yang dilarang, penyelesaian sengketa, peran pemerintah dan masyarakat, penyidikan, serta ketentuan pidana.

Selanjutnya, Instruksi Presiden Nomor 2 Tahun 2001 Tentang Penggunaan Komputer dengan Aplikasi Komputer Berbahasa Indonesia. Kehadiran Inpres ini dilatarbelakangi setidaknya oleh tiga hal: pertama, menyiapkan SDM baik masyarakat maupun aparatur negara yang mampu mengoperasikan perangkat teknologi (komputer) dalam rangka menghadapi era globalisasi; kedua, kendala pemahaman bahasa asing pada aplikasi komputer yang menyebabkan kesulitan pengoperasian komputer bersangkutan; ketiga, perlunya aplikasi komputer berbahasa Indonesia untuk memudahkan pengguna (masyarakat/ aparatur negara) dalam melaksanakan kegiatannya, sekaligus sebagai alternatif pilihan bahasa pada aplikasi komputer.

Presiden saat itu, Abdurrahman Wahid, melalui Inpres Nomor 2 Tahun 2001 menginstruksikan khususnya kepada Menteri Riset dan Teknologi serta Menteri Pendidikan Nasional untuk melaksanakan kegiatan pembakuan istilah-istilah komputer ke dalam bahasa Indonesia, menyusun aplikasi komputer berbahasa Indonesia berikut pedoman pemakaiannya dengan menggandeng para ahli serta pihak-pihak terkait. Sebagai tindak lanjut, pemerintah melalui Pusat Bahasa kemudian membentuk tiga Kelompok Kerja (Pokja) yakni Pokja Pembakuan Istilah Teknologi Informasi, Pokja Perangkat Lunak, serta Pokja Sosialisasi dan Implementasi. Tugas utama 
yang diemban oleh ketiga Pokja ini, khususnya Pokja Pembakuan Istilah, ialah merumuskan pedoman pembakuan istilah, pedoman pemakaian istilah, dan menghimpun daftar (senarai) awal sekitar 700 istilah dalam bidang teknologi informasi. Lalu, pada tahap berikutnya direncanakan sekitar 4000 istilah yang akan dipadankan hingga tahap akhir dalam bentuk penyusunan kamus (Artikel Ristek, 2001).

Setelah dihimpun, senarai padanan yang berisi sekitar 629 istilah kemudian dirilis sebagai tahap awal. Reaksi dari masyarakat bermacam-macam. Ada yang mendukung usaha ini, namun ada pula yang menentangnya. Tanggapan beragam yang muncul mengarah tidak hanya pada bentuk sosialisasi yang dilakukan pemerintah, tetapi juga pada isi senarai padanan yang dihimpun oleh tim perumus. Onno W. Purbo, salah seorang anggota tim perumus istilah TI dalam wawancara dengan detik.com (9/5/2001) menawarkan solusi terkait sosialisasi dan implementasi Inpres Nomor 2 Tahun 2001 dalam bentuk insentif kepada pembuat, pengembang, atau pengecer perangkat lunak berbahasa Indonesia. Menurutnya, insentif yang diberikan dapat berupa pemotongan pajak hingga 50\%. Cara ini diharapkan dapat memacu, tidak saja upaya pengembangan aplikasi, tetapi juga pemakaian aplikasi komputer berbahasa Indonesia di kalangan pengguna. Untuk pemerintah, cara ini menurut Onno dirasa lebih efektif daripada repot membentuk satgas, berhutang, dan sebagainya.

Lima belas tahun kemudian, atau setelah konvergensi media menjadi hal yang lumrah di Indonesia, penggunaan istilah-istilah komputer berbahasa Indonesia tersebut idealnya telah merata, lebihlebih di kalangan pengguna pemula komputer seperti yang diisyaratkan dalam Inpres Nomor 2 Tahun 2001. Tetapi pada kenyataannya, pengaruh dari Inpres tersebut belum maksimal. Sebagian besar pengguna komputer dan internet di Indonesia masih setia dengan bahasa Inggris sebagai bahasa antarmuka/bahasa istilah yang digunakan ketika mengoperasikan komputer atau ketika sedang berselancar di internet.

Dalam rangka mencari solusi atas permasalahan di atas, perlu dilakukan kajian komprehensif yang menjangkau tidak hanya analisis terhadap kesalahan ejaan dalam kamus istilah komputer berbahasa Indonesia, tetapi juga melingkupi faktor eksternal seperti pengaruh evolusi media terhadap kebijakan yang dikeluarkan pemerintah, posisi bahasa Indonesia dalam pergaulan internasional, domestikasi terhadap istilah asing, kurang apresiatifnya media terhadap istilah-istilah yang dibakukan, persentase software berbahasa Indonesia yang minim, gengsi bahasa, dan sebagainya. Aspek kajian ini membentang dari topik perencanaan bahasa, metamorfosis media (mediamorfosis), hingga kaidah pembakuan peristilahan komputer. 
Tulisan ini bertujuan untuk merumuskan secara tekstual kendala penggunaan istilah teknologi informasi berbahasa Indonesia. Oleh karena itu kemudian dilakukan kajian teks terhadap berbagai istilah komputer berbahasa Indonesia meliputi pembicaraan tentang prinsip kebakuan istilah komputer. Rujukan utama materi ini ialah pendekatan komunikatif yang dikemukakan oleh Agnes Kukulska-Hulme (1999 dan 2000).

\section{KONSEP DAN KERANGKA TEORI}

\section{KONSEP}

\section{Konsep Istilah}

Dalam Pedoman Umum Pembentukan Istilah (PUPI, 2007:9) istilah dijelaskan sebagai kata atau frasa untuk nama atau lambang dan yang dengan cermat mengungkapkan makna konsep, proses, keadaan atau sifat yang khas dalam bidang ilmu pengetahuan, teknologi, dan seni, sedangkan tata istilah (terminologi) adalah perangkat asas dan ketentuan pembentukan istilah serta kumpulan istilah yang dihasilkannya.

Dalam pembentukan istilah perlu diperhatikan persyaratan dalam pemanfaatan kosakata bahasa Indonesia sebagai berikut (PUPI, 2007:10).

a. Istilah yang dipilih adalah kata atau frasa yang paling tepat untuk mengungkapkan konsep termaksud dan yang tidak menyimpang dari makna itu; b. Istilah yang dipilih adalah kata atau frasa yang paling singkat di antara pilihan yang tersedia yang mempunyai rujukan sama;

c. Istilah yang dipilih adalah kata atau frasa yang bernilai rasa (konotasi) baik;

d. Istilah yang dipilih adalah kata atau frasa yang sedap didengar (eufonik);

e. Istilah yang dipilih adalah kata atau frasa yang bentuknya seturut kaidah bahasa Indonesia.

\section{Konsep Teknologi Informasi}

Dalam bidang teknologi informasi khususnya terkait istilah yang digunakan di layar komputer/internet (interface/ antarmuka), Agnes Kukulska-Hulme telah menyatakan bahwa sikap paling tepat dalam menyikapi istilah komputer yang dapat mengakomodasi pemahaman para penggunanya ialah dengan menganggap para pengguna komputer sebagai pembelajar bahasa (1999:4). Pandangan ini bila dikaitkan dengan persyaratan peristilahan yang baik di atas (PUPI) bertujuan agar para "pembuat" istilah tidak sekedar mementingkan aspek teknis penciptaan istilah, tetapi juga mengedepankan operasional istilah tersebut di tangan para pengguna. Asumsinya jelas, ribuan istilah atau padanannya akan menjadi sia-sia ketika tidak digunakan oleh para penggunanya.

Dalam rangka memudahkan pemahaman sebagai kerangka analisis terhadap 
istilah-istilah yang digunakan dalam suatu aplikasi baik itu istilah asli maupun padanannya, Kukulska-Hulme (2000:596) merumuskan delapan kategori yang dapat menjadi dasar untuk melakukan penelitian lebih lanjut.

1. Identifikasi kata-kata yang memiliki bentuk serupa;

2. Identifikasi kata-kata yang memiliki kemiripan makna;

3. Identifikasi potensi kata-kata ambigu;

4. Identifikasi kata-kata yang mengandung makna budaya tertentu;

5. Identifikasi keterangan yang bertumpuk;

6. Identifikasi kata-kata dan ekspresi idiomatik;

7. Perhatikan cara pelafalan istilah oleh pengguna komputer;

8. Susun kata-kata yang berkolokasi atau berhubungan satu sama lain.

Kedelapan kategori yang diajukan oleh Kukulska-Hulme tersebut dalam hubungannya dengan para pengguna komputer di Indonesia, menyasar pada kompetensi berbahasa Inggris yang dimiliki oleh para pengguna sebagai dasar pengoperasian komputer. Kesulitan yang kemungkinan dihadapi oleh para pengguna komputer di Indonesia kemudian ialah bahwa mayoritas diantaranya bukan penutur asli bahasa Inggris. Imbasnya, para pengguna mendapat kesulitan ganda. Pertama, mereka terkendala pemahaman terhadap bahasa Inggris. Kedua, mereka terkendala makna khusus istilah teknologi informasi yang bahkan penutur asli bahasa Inggris juga dibuat bingung olehnya.

\section{KERANGKA TEORI}

Menurut Kukulska-Hulme (2000: 587), Penerjemahan istilah komputer ke dalam bahasa setempat tidak selalu mungkin dan tepat dilakukan secara teknis, politik, maupun ekonomi. Sebagian besar pengguna memilih menggunakan versi asli dari istilah komputer karena faktor bahasa bawaan piranti lunak atau alasan profesi yang di dalamnya para pengguna bekerja dengan perantaraan bahasa Inggris. Para pengguna ini yang dikategorikan sebagai bukan penutur asli bahasa Inggris, adalah mereka yang memilih menggunakan versi asli antarmuka berbahasa Inggris, sebelum akhirnya penerjemahan mengambil alih.

Pada web dan internet, tak terhitung jumlah pengguna yang menyatakan pentingnya bahasa dalam sebuah antarmuka komputer (Kukulska-Hulme, 2000:588). Sayangnya terdapat penekanan kebutuhan yang berbeda antara grup formal-informal dan organisasi komersial-nonkomersial dalam menyikapi pentingnya rancangan antarmuka yang dapat dipahami bersama baik oleh penutur asli maupun oleh para penutur bukan berbahasa Inggris. 
Dilihat dari perspektif pemerolehan bahasa kedua, tantangan terbesar yang dihadapi oleh sebuah program komputer adalah cara agar bahasa Inggris dapat dipahami oleh para pengguna dengan berbagai latar belakang berbeda (Kukulska-Hulme, 2000:588). Hal ini termasuk mengurutkan kendala-kendala yang dihadapi oleh para penutur bukan berbahasa Inggris ketika berinteraksi dengan istilah-istilah komputer yang ada.

Sejalan dengan ini, setiap pengguna komputer pada dasarnya dipandang sebagai pembelajar bahasa karena harus berhadapan dengan sejumlah istilah bermakna khusus yang belum pernah dikenali sebelumnya, atau mereka berhadapan dengan istilah yang telah dikenali, tetapi ternyata memiliki makna yang berbeda. Dalam kondisi ini, pengguna yang bukan penutur asli bahasa Inggris menemui kendala lebih. Ini disebabkan selain mereka harus memahami bentuk dan struktur bahasa Inggris, mereka juga terhambat oleh kendala makna khusus seperti yang dialami oleh para penutur asli.

Agnes selanjutnya memetakan kesulitan-kesulitan yang dialami oleh para pengguna komputer nonpenutur bahasa Inggris yang disebutnya sebagai kendala konteks verbal (meliputi konteks gramatikal dan semantik). Ia membagi kendalakendala tersebut menjadi sepuluh bagian (2000:590), yakni words similar in form, culture-specific meanings, incorrect pronunciation, abbreviations, words related in meaning, semi-technical terms, ambiguous words, stacked modifiers, false friends, and idiomatic expressions.

Di Indonesia, kesepuluh kendala konteks verbal di atas diasumsikan muncul sebagai hambatan dalam penggunaan istilah teknologi informasi yang telah dipadankan. Dominasi bahasa Inggris, termasuk faktor kedekatan bahasa Indonesia dengan bahasa serumpun dapat menjadi wujud konkrit yang merepresentasikan kendala-kendala tersebut.

\section{PEMBAHASAN}

Suatu padanan istilah komputer dalam konteks penerjemahan, penyerapan, maupun gabungan keduanya- pada dasarnya memiliki hambatan-hambatan tertentu untuk digunakan oleh para pengguna baik itu oleh para penutur asli (bahasa Inggris), lebih-lebih lagi oleh para penutur bahasa non-Inggris. Kukulska-Hulme (2000:590-596) mengidentifikasi sepuluh kendala yang kerap dialami oleh para pengguna komputer ketika berhadapan dengan istilah-istilah yang terdapat pada antarmuka (interface) suatu aplikasi komputer/internet. Kesepuluh hambatan tersebut yakni kata-kata yang memiliki bentuk serupa, makna budaya yang terkandung dalam istilah terntu, pelafalan yang keliru, singkatan, sinonim, istilah semi teknis, kata -kata ambigu, keterangan yang bertumpuk, istilah dwibahasa yang identik, serta ekspresi idiomatik. 


\section{Keserupaan Bentuk Kata}

Istilah yang termasuk dalam kategori ini ialah kata-kata yang memiliki bentuk serupa serta kedekatan makna seperti border dengan box pada Microsoft Word, clear dengan close, refresh dengan restore, expand dengan extend, form dengan format, footer dengan footnote, mark dengan bookmark, serta clip dengan click. Pada Senarai Padanan Istilah, kata yang termasuk dalam kategori ini ialah salin (copy) dengan salindia (slide).

\section{Makna Budaya}

Dalam suatu kebudayaan, orang cenderung memiliki pemahaman yang merata terhadap suatu makna, berbeda dengan komunikasi lintas budaya yang biasanya akan menimbulkan kesalahpahaman. Bahasa Inggris saja secara geografis dan budaya memiliki berbagai perbedaan, khususnya terhadap makna istilah yang sama. Dalam konteks pendidikan, antara British English dengan American English memiliki pemaknaan yang berbeda terhadap kata faculty dan graduate. Penelitian yang dilakukan oleh Evers dkk. (KukulskaHulme, 2000:592) menunjukkan bahwa pada situs pendidikan tertentu, istilah faculty dimaknai sebagai 'subjek', 'bangunan', atau 'staf akademis' tergantung pada latar belakang linguistik dan budaya penggunanya (dalam hal ini Inggris, Belanda, dan Sri Lanka).

Pada kasus peristilahan komputer berbahasa Indonesia, permasalahan semacam ini mengemuka mengingat keanekaragaman bahasa daerah serta penggunaan bahasa serumpun sebagai padanan. Semangat pemberdayaan bahasa daerah sebagai padanan istilah teknologi informasi memiliki nilai positif pemerkayaan kosakata bahasa Indonesia. Namun di sisi lain, upaya ini tidak jarang menimbulkan kebingungan di kalangan para pengguna istilah bersangkutan karena adanya variasi makna termasuk perbedaan konotasi terhadap makna padanan tersebut, misalnya istilah liwat (bellmouth) dengan julat (range). $\mathrm{Li}$ wat di Kamus Besar Bahasa Indonesia bermakna 'lewat' dan 'persetubuhan sesama jenis' sementara bellmouth ialah bagian dari turbin gas yang berfungsi membagi udara agar merata saat memasuki turbin. Kemudian istilah julat yang merupakan padanan dari range (jangkauan). Dalam beberapa dialek bahasa Sasak, julat bermakna 'terbakar' atau 'kebakaran.'

Penggunaan kata serumpun sebagai padanan pun menemui masalah yang kurang lebih sama. Bedanya, intensitas ketidakpahaman atau kesalahpahaman terhadap makna istilah bersangkutan menjadi lebih tinggi. Hal ini patut diiyakan mengingat bila dibandingkan dengan padanan yang bersumber dari bahasa daerah, padanan dari bahasa serumpun relatif kurang dikenal atau bahkan tidak dikenal sama sekali oleh penutur bahasa Indonesia. Kerap kali, makna yang dihasilkan kemudian tidak dipahami dan dikhawatirkan akan 
menimbulkan kebingungan dalam pengoperasian aplikasi komputer yang mengandung padanan-padanan tersebut di dalamnya. Istilah-istilah yang terdapat dalam Glosarium Istilah Teknologi Informasi (Pusat Bahasa) seperti lembatang (sheet), pengaya (add-ons), gambatang (drawing), purata (average), lebatang (bandwidth), taklikan (collation), juru kalkir (tracer), simbul (symbol), forsa (force), ananta (infinite), kinandar (operand), sungap (sink), dan masih banyak lainnya disinyalir bersumber dari bahasa serumpun sehingga pencariannya dalam tulisan-tulisan terkait sukar ditemukan. Jika dikaitkan dengan efektivitas penggunaan istilah tersebut dalam suatu aplikasi, akan dibutuhkan kehadiran rujukan setidaknya KBBI atau Kamus Teknologi Maklumat Perisian (Dewan Bahasa dan Pustaka).

Di samping makna yang tidak dipahami, permasalahan lain yang muncul pada berbagai padanan dalam Senarai Padanan Istilah maupun Glosarium Istilah Teknologi Informasi ialah konotasi yang dihasilkan oleh makna padanan bersangkutan. Terdapat padanan yang mengandung konotasi negatif, ada juga yang mengandung konotasi seksual. Beberapa istilah yang dapat diajukan sebagai contoh ialah sebagai berikut.

1. liwat (bellmouth)

2. kutu (bug)

3. tembolok (cache)
4. jurik(daemon)

5. pemayar selaput (film scanner)

6. tembok api (firewall)

7. menangan; pembantu (handle)

8. abah-abah (harness)

9. kabel tersedak (impregnated cable)

10. desak-desakan (jam)

11. tongkat joy; tongkat ria (joystick)

12. sosok bawah (lower case)

13. sosok atas (upper case)

14. tangan-tangan carong (mike boom)

15. saling asing (mutual exclusion)

16. barang tetek tengah (odds)

17. lewat pagar (overscan)

18. spesial pasta (paste special)

19. ragam kacau balau (promiscuous mode)

20. tulang punggung radio (radio trunking)

21. salindia (slide)

22. tuan lalu lintas (traffic lever).

23. cakram keras bisa pindah (removable harddisk)

\section{Pelafalan Yang Keliru}

Bagi orang yang sedang belajar bahasa Inggris, kontak pertama dengan istilahistilah baru berisiko menimbulkan kesalahpahaman yang bersumber dari kesalahan dalam pelafalan istilah 
(Kukulska-Hulme, 2000:591). Ketika para pengguna komputer berhadapan dengan berbagai istilah yang ada di monitor, dengan ketiadaan pelafalan bunyi sebagai bantuan, para pengguna kemudian merekareka pelafalan yang tepat terhadap istilah yang ada. Mereka kemudian tidak menyadari bahwa lafal previews berbeda dengan previous, lafal access berbeda dengan assess. Terlebih lagi, kata yang salah dilafalkan terkadang menyerupai kata dalam bahasa pertama pengguna, sehingga kemungkinan kesalahan makna menjadi lebih besar. Contohnya ialah type yang kerap salah dilafalkan sebagai tip atau teep. Type (Bahasa Inggris) berhubungan dengan mengetik atau mencetak, berbeda ketika dilafalkan sebagai tip (yang dalam bahasa Polandia 'typ') hanya merujuk pada kategorisasi.

Pelafalan bahasa Indonesia terhadap istilah asli teknologi informasi juga kurang lebih demikian. Para penutur bahasa Indonesia cenderung mengikuti pola pelalafan kata bahasa Indonesia ketika melafalkan kosakata bahasa Inggris. Wajar jika kemudian kita menyaksikan istilah charge dilafalkan sebagai "cas", save dilafalkan sebagai "sip/sif", facebook dilafalkan sebagai "fesbuk", e-mail dilafalkan sebagai "imel", paste dilafalkan sebagai "paste", eject dilafalkan sebagai "ejek", font dilafalkan sebagai "pon”, jam dilafalkan sebagai "jam", mouse dilafalkan sebagai "maus/mous", redo dilafalkan sebagai "redo", dan undo dilafalkan sebagai "ando/ undo.”

Karena sudah terlanjur akrab, padanan istilah charge juga merembet pada derivasinya yang lain semisal charger yang dilafalkan menjadi "cas-casan." Lema save ketika diucapkan sebagai "sip" memiliki konotasi persetujuan, kesiapan, serta sanjungan atas sesuatu yang ditambahi oleh ekspresi acungan jempol. e-mail ketika dilafalkan sebagai "imel” berkonotasi dengan nama panggilan seseorang, khususnya perempuan. Paste sebagai pasangan dari copy lazimnya dilafalkan sebagai "kopi paste", yang mau tidak mau merujuk pada jenis minuman. Lema eject juga demikian. Perintah yang biasanya dikenakan pada media bergerak seperti flash disk atau hard disk external ini memiliki konotasi pada tindakan mencela orang lain. Istilah ini cenderung dipahami sebagai "cabut" atau "lepas", sehingga ketika ia digabung dengan lafal ejek, lengkaplah "penderitaan" media bergerak tersebut: sudah diejek, dicabut pula.

\section{Singkatan}

Materi-materi pengajaran bahasa Inggris dan kamus dwibahasa biasanya memasukkan informasi perihal bentuk singkatan (Kukulska-Hulme, 2000:593). Bentuk-bentuk ini sederhananya dapat ditemukan pada iklan-iklan mini di surat kabar. Serupa dengan hal tersebut, pada dunia komputasi turut dikenal berbagai singkatan yang memerlukan pendalaman 
untuk dipahami fungsi dan kegunaannya. Istilah-istilah pada papan Qwerty seperti ESC, INS, DEL, PRTSC SYSRQ, PGUP, PGDN, CAPSLOCK, CTRL, FN, dan ALT memerlukan pemahaman lebih lanjut sebelum dapat difungsikan secara optimal oleh para penggunanya.

Penggunaan singkatan atau akronim sebagai istilah teknologi informasi sepertinya dilatari oleh beberapa pertimbangan teknis dan ekonomis misalnya bentuk yang lebih ringkas serta ruang pada papan kunci/ layar komputer yang lebih sempit. Masalahnya kemudian ialah para pengguna memerlukan dua tahap pembelajaran untuk dapat mengoperasikan suatu perintah dengan benar. Pertama kali, para pengguna komputer harus paham bahwa DEL adalah singkatan untuk delete. Berikutnya, mereka harus paham bahwa delete berfungsi untuk menghapus suatu karakter atau suatu berkas.

\section{Sinonim}

Kata-kata yang tidak mirip secara bunyi maupun ejaan, tetapi memiliki kedekatan makna biasanya menghadirkan kesulitan tertentu, misalnya menentukan perbedaan antara mistake, error, dan fault (Kukulska-Hulme, 2000:591). Ketiganya merupakan sinonim yang sering digunakan namun salah ditafsirkan. Pasangan bentuk lainnya yakni contents dengan index, search dengan find, dan directory dengan file. Kesemuanya oleh Kukulska-Hulme dianggap dapat menimbulkan masalah yang sama bagi penutur asli maupun penutur nonbahasa Inggris.

Hal serupa dapat ditemukan baik pada Senarai Padanan Istilah maupun pada Glosarium Istilah Teknologi Informasi. Istilah account dipadankan dengan akun dan rekening, yang mana keduanya di Indonesia cenderung memiliki konteks penggunaan yang berbeda. Perintah yang lazim ada di internet ketika hendak mendaftar pada suatu media sosial misalnya ialah buat akun (create account), bukan buat rekening. Padanan yang kedua biasanya terkait dengan account sebagai tagihan pembayaran atau tabungan (rekening listrik, rekening PDAM, rekening bank).

Kemudian ada juga istilah character yang dipadankan dengan aksara dan karakter. Aksara merujuk pada sistem tanda grafis sebagai satu kesatuan dan juga merujuk pada huruf entitas tunggal, sedangkan karakter merujuk pada sistem tanda grafis yang tidak hanya terdiri atas huruf, tetapi juga tanda baca, kode, simbol, emosikon, dan sebagainya. Berdasarkan pengertian di atas maka penggunaan padanan aksara dan karakter juga memiliki perbedaan.

Contoh:

"Satu buah pesan singkat setara dengan 160 karakter." (bukan 160 aksara)

"Aksara Pallawa merupakan salah satu yang tertua di dunia." (bukan karakter Pallawa) 


\section{Istilah Semi Teknis}

Yang dimaksud dengan istilah semi teknis ialah kata-kata yang dalam keseharian tidak ditemukan dalam situasi pembelajaran bahasa (Kukulska-Hulme, 2000:593). Kata-kata seperti paste, merge, dan flush akan jauh dari pemahaman para penutur nonbahasa Inggris. Cropping akan menjadi istilah yang tidak populer, merujuk pada keberadaannya dalam bidang desain grafis. Kosakata semi teknis akan menyulitkan pengguna yang berlatarbelakang nonteknis, terlebih lagi jika istilah semi teknis tersebut tidak dijelaskan. Kata lain yang dapat menjadi contoh ialah kata open. Makna kata ini dalam istilah komputasi berbeda dengan maknanya di keseharian. Perintah "open a location"pada sebuah situs internet tidak bermakna 'membuka sebuah lokasi', tetapi 'mengunjungi sebuah dokumen berdasarkan alamat yang tertera' (Kukulska-Hulme, 2000:893).

Ketika berhadapan dengan istilah teknis atau semi teknis, beberapa penutur dilaporkan menghindari maknanya sama sekali, dan lebih memilih untuk mempelajari seperangkat petunjuk yang bergaris bawah, atau mengingat-ingat posisi suatu item pada sebuah menu. Jika versi terbaru dari perangkat lunak tersebut dirilis dan istilah-istilah yang terdapat di dalamnya berbeda dengan versi terdahulu maka para pengguna komputer dengan latar belakang penutur nonbahasa Inggris tidak akan mampu beradaptasi secepat penutur aslinya (Kukulska-Hulme, 2000:594).
Di Indonesia, istilah-istilah semi teknis pada Senarai Padanan Istilah maupun Glosarium Istilah Teknologi Informasi dapat ditemukan misalnya pada istilah alamat (address), penyangga (buffer), gunting; potong (cut), seret (drag), sejarah (history), kancing (lock), resolusi (resolution), pudar (sleep), ubinan (tile), serta jendela (window). Kata alamat dalam bahasa sehari-hari berbeda dengan alamat yang merujuk pada URL (Uniform Resource Locator) di sebuah situs internet. Jika alamat dalam keseharian biasanya dimulai dari unit terkecil seperti $\mathrm{RT} / \mathrm{RW}$, dusun, desa/kelurahan, kecamatan, kabupaten/kota, provinsi, hingga negara, alamat dalam bidang teknologi informasi cenderung sebaliknya. Yang didahulukan unsur terbesar diikuti oleh path yang lebih spesifik. Contohnya untuk merujuk pada tulisan Steven Haryanto tentang pengindonesiaan istilah asing pada laman master.web.id, alamat yang dituliskan ialah http:// www.master.web.id/mwmag/issue/01/ content/bdt-istilah_asing/bdtistilah_asing.html.

\section{Kata-Kata Ambigu}

Kemungkinan perbedaaan penafsiran makna, yang dikenal sebagai ambiguitas, merupakan hal yang turut terjadi dalam peristilahan teknologi informasi. Bahasa Inggris memiliki berbagai nomina dan adjektiva yang memiliki bentuk yang sama dengan verba atau yang berfungsi sebagai 
verba seperti file, block, log, extract, frame, chat, screen, release (Kukulska-Hulme, 2000:592). Jika kata-kata tersebut berdiri sendiri pada pilihan menu atau pada tombol, akan sangat sulit memprediksi kecenderungan maknanya. Sama halnya dengan para penutur asli, para penutur nonbahasa Inggris dapat dibuat bingung. Keterbatasan pengetahuan bahasa Inggris dapat mendorong mereka untuk menduga suatu makna tertentu yang belum tentu merupakan makna yang tepat.

Pada Senarai Padanan Istilah dan Glosarium Istilah Teknologi Informasi, kata-kata yang tergolong ambigu juga dapat ditemukan. Lema semisal gugur (abort), urut (sort), kutu (bug), tembolok (cache), penangkapan (capture), jurik (daemon), seret (drag), pancar (eject), ketuk (hit), desak-desakan (jam), tongkat joy; tongkat ria (joystick), lewat pagar (overscan), cekatan (wizard) merupakan beberapa contohnya.

\section{Keterangan Bertumpuk}

Modifier adalah kata, frasa, atau klausa yang berfungsi sebagai adjektiva atau adverbia yang menerangkan kata atau kelompok kata lain. Ketika berfungsi sebagai adjektiva modifier menerangkan nomina, sedangkan ketika berfungsi sebagai adverbial modifier menerangkan verba, adjektiva, atau adverbial lainnya. Pada beberapa variasi bahasa Inggris, terdapat kecenderungan untuk meletakkan sekumpulan modifier di depan sebuah nomina untuk mengubah maknanya (KukulskaHulme, 2000:594).

Easy open pack merupakan contoh label kemasan yang bermakna 'ini adalah kemasan yang mudah dibuka'. Struktur seperti ini dapat menyulitkan untuk dipahami bagi pihak yang tidak familiar dengan bidang tersebut. Terdapat sejumlah contoh tipe struktur semacam ini pada berbagai aplikasi seperti the Re-enter Password Box yang bermakna 'kotak untuk memasukkan ulang kata sandi' (Ms. Excel), serta the Customise Toolbars Dialog Box yang bermakna 'kotak dialog untuk kustomisasi opsi batang alat' (Ms. PowerPoint). Gaya mengemas tulisan yang sangat ringkas, dikombinasikan dengan terminologi baru, menghasilkan ekspresi yang janggal dan membingungkan seperti halnya the most recently ungrouped group (Ms. PowerPoint help).

\section{Bentuk Dwibahasa Identik}

'False friend' merupakan permasalahan umum pada bahasa yang bertalian, dan menyulitkan penutur bahasa yang satu dalam mempelajari dan menggunakan bahasa lainnya. Bahasa Inggris dan bahasa lainnya berbagi banyak kosakata Yunani dan Latin yang maknanya berkembang seiring perubahan zaman. Kata report (Prancis) meskipun terlihat seperti report (Inggris) dapat bermakna penangguhan atau transfer gambar. Kata yang mirip juga dapat menjadi masalah, seperti kata replace (Inggris) yang 
terlihat serupa dengan replacer (Prancis), padahal kata yang kedua bermakna 'mengembalikan' bukan 'menggantikan sesuatu dengan yang lain'. Delay (Inggris) mirip dengan délai yang dalam bahasa Prancis bermakna 'waktu yang dibolehkan'. Contoh yang lain yaitu kata cancellare (Italia) berkorespondensi dengan makna kata delete (Inggris) meskipun bentuknya mirip dengan cancel,kata clasifición (Spanyol) berkorespondensi dengan makna kata sort (Inggris); dirección (Spanyol) berkorespondensi dengan address (Inggris) dan sebagainya.

Permasalahan seperti ini pada Senarai Padanan Istilah dan Glosarium Istilah Teknologi Informasi juga ditemukan. Kedekatan antara bahasa Indonesia dengan bahasa Melayu yang digunakan oleh Malaysia dan Brunei Darussalam tampaknya menjadi alasan utama kehadiran bentuk semacam ini. Terlebih lagi, baik Senarai Padanan Istilah maupun Glosarium Istilah Teknologi Informasi disusun dengan melibatkan para ahli dari kedua negara tetangga tersebut.

Istilah berpusing (spin) dalam bahasa Melayu berkorespondensi dengan istilah berputar dalam bahasa Indonesia. Bentuk pusing dalam bahasa Indonesia memiliki makna 'sakit kepala'. Kemudian istilah Melayu percuma (free) yang dalam bahasa Indonesia lebih dikenal dengan sebutan gratis. Diksi percuma dalam bahasa Indonesia lebih sering disebut sebagai cumacuma. Selain itu ada juga istilah tak berguna (idle) yang jika merujuk pada fungsinya pada mesin pencetak, di Indonesia memiliki konotasi 'menunggu untuk bekerja'. Istilah tak berguna dalam bahasa Indonesia bermakna 'tidak mampu melakukan pekerjaan apa-apa'. Istilah sesuka (optional) juga menyuratkan hal yang sama. Dalam bahasa Indonesia, kata ini bermakna 'sekehendak hati; semaunya' Diksi yang sesuai dengan makna yang dikandung oleh istilah optional ialah pilihan. Lalu ada istilah mengopak (poke) yang dalam aplikasi Facebook berbahasa Indonesia dipadankan dengan colek. Istilah mengopak dalam KBBI bermakna 'menyalakan kembali api yang hampir padam (dengan diembus dan sebagainya)'. Mungkin maksudnya adalah menyambung tali silaturrahmi.

\section{Ekspresi Idiomatik}

Bentuk idiom pada Senarai Padanan Istilah dan Glosarium Istilah Teknologi Informasi mungkin adalah tangan-tangan $\mathrm{ca}$ rong (Mike Boom). Agak sulit menemukan kosakata aslinya di internet sebab yang lebih dikenal ialah boom mic.Kemudian ada juga istilah yang entah dapat dikategorikan sebagai idiom atau tidak, tetapi mengandung konotasi seksual yang jauh berbeda dengan makna yang dikandung oleh istilah aslinya. Istilah tersebut adalah barang tetek tengah (Odds). Apakah yang dimaksud ialah rasio (odds ratio)? Bagaimana dengan tulang punggung radio 
(Radio Trunking), apakah maknanya setara dengan tulang punggung keluarga? Lalu bagaimana juga dengan kabel tersedak (impregnated cable), apakah konotasinya sama dengan "orang yang tersedak"?

\section{SIMPULAN}

Berdasarkan hasil analisis data dan pembahasan yang dilakukan diperoleh simpulan sebagai berikut. Kendala penggunaan istilah teknologi informasi berbahasa Indonesia bersumber dari faktor pengguna teknologi serta faktor padanan istilah yang dihasilkan. a) Penelitianpenelitian terdahulu menjelaskan bahwa penggunaan bahasa Inggris yang terlanjur melekat pada aplikasi komputer dan sejenisnya membuat penerimaan praktisi dan para pengguna komputer terhadap istilah berbahasa Indonesia menjadi rendah. Keengganan untuk beralih menggunakan istilah berbahasa Indonesia salah satunya dipicu kekhawatiran bahwa istilah tersebut justru akan membingungkan ketika diterapkan dalam penggunaan sehari-hari. Masalah kepopuleran istilah asing menjadi alasan penolakan terhadap istilah teknologi informasi berbahasa Indonesia. Di samping itu, penolakan para praktisi terhadap pengindonesiaan istilah juga merujuk pada kegagalan Jerman dan Prancis dalam melaksanakan kegiatan yang sama. Yang lebih meresahkan, penelitian yang dilakukan oleh Sari (2014:80) menunjukkan bahwa hanya $33,39 \%$ dari
629 istilah teknologi informasi pada Senarai Padanan Istilah yang dikenal oleh kalangan mahasiswa. Padahal istilah-istilah tersebut adalah istilah asli berbahasa Inggris yang notabene diasumsikan lebih populer daripada padanannya dalam bahasa Indonesia. Lantas berapa persentase kepopuleran istilah teknologi informasi berbahasa Indonesia? b) Yang kedua, faktor padanan istilah dianggap masih mengandung berbagai masalah. Kajian dengan menggunakan Pendekatan Komunikatif menunjukkan bahwa kendala pemahaman terhadap istilah-istilah teknologi informasi berbahasa Indonesia berasal dari istilah-istilah yang memiliki bentuk serupa, makna budaya yang terkandung dalam istilah tertentu, pelafalan yang keliru, singkatan, sinonim, istilah semi teknis, kata-kata ambigu, keterangan yang bertumpuk, istilah dwibahasa yang identik, serta ekspresi idiomatik.

\section{UCAPAN TERIMA KASIH}

Terima kasih penulis ucapkan kepada Mitra Bebestari yang telah memberikan saran dan masukan yang bermanfaat untuk perbaikan artikel ini.

\section{DAFTAR PUSTAKA}

Anonim. Instruksi Presiden Nomor 2 Tahun 2001 Tentang Penggunaan Komputer dengan Aplikasi Komputer Berbahasa Indonesia.

Kukulska-Hulme, A. 1999. Language and Communication (Essential Concepts 
for User Interface and Documentation Design. New York: Oxford University Press.

.2000. "Communication with Users: Insights from Second Language Acquisition." Interacting with Computers, 12 (6), pp. 587-599.

Purbo, Onno W. 2001. "Pengindonesiaan Produk Komputer Timbulkan ProKontra", wawancara dengan detikcom pada Rabu, 09 Mei 2001.

Sari, C.A. 2014. "Tanggapan Mahasiswa di Kota Surakarta Terhadap Pengindonesiaan Istilah Asing Bidang Perkomputeran (Kajian Sosiolinguistik)." Masters Thesis, Universitas Sebelas Maret.

Tim. 2005. Kamus Besar Bahasa Indonesia (Edisi Ketiga). Jakarta: Balai Pustaka.

Tim. 2007. Pedoman Umum Pembentukan Istilah. Jakarta: Pusat Pembinaan dan Pengembangan Bahasa Depdiknas RI.

Undang-Undang Nomor 11 Tahun 2008 Tentang Informasi dan Transaksi Elektronik.

Undang-Undang Nomor 24 Tahun 2009 Tentang Bendera, Bahasa, dan Lambang Negara serta Lagu Kebangsaan.

Haryanto, Steven. 2002. "Istilah Asing: Indonesiakan atau Biarkan?", dari laman http://www.master.web.id/ mwmag/issue/01/content/bdtistilah_asing/bdt-istilah_asing.html.

http://www.ristek.go.id/index.php/module/ News+News/id/296/pdf 